\title{
The Secular Stagnation of Productivity Growth *
}

\author{
Servaas Storm ${ }^{\dagger}$
}

\section{Working Paper No. 108}

\author{
December $12^{\text {th }}, 2019$
}

\begin{abstract}
The concern that an economy could experience persistent stagnation, caused by a structural weakness of aggregate demand, goes back to Alvin Hansen's (1939) thesis of 'secular stagnation'. Hansen's thesis has been revived in recent times, when it became clear that productivity and potential growth in the OECD countries have been declining for decades. However, in line with deep-rooted theoretical beliefs, that inadequate demand can only affect growth in the short run, secular stagnation (of potential growth) is treated as an exclusively supply-side problem, the root of which is a worrying steady decline in productivity growth. This paper argues that it is a mistake to dismiss secular demand stagnation as main cause of declining potential growth in the OECD. We argue that the theoretical case for demand-caused secular stagnation is strong and empirical evidence that it has affected the U.S. economy after the mid-1970s is entirely convincing. Demand is leading supply, also in the long run. Hansen had it right, after all.
\end{abstract}

\footnotetext{
* This paper will be published as a chapter in The Handbook of Economic Stagnation, edited by L. Randall Wray and Flavia Dantas (2020). Amsterdam: Elsevier/Academic Press. The author is grateful to the Institute for New Economic Thinking for financial support (under individual grant \#INO 1800015).

Delft University of Technology.

https://doi.org/10.36687/inetwp108
} 
JEL Codes: E02; E12; E31; F02; F15.

Keywords: Unbalanced growth, secular stagnation, total factor productivity, labor productivity growth, Solow residual, dual economy. 


\section{The 'slow-moving turtle'}

The anemic economic recovery after the Great Financial Crisis of 2008-09 has revived interest in the hypothesis of secular stagnation, which was first proposed in December 1938 by Alvin E. Hansen in a foreboding Presidential Address to the American Economic Association. Hansen's original idea was that the feeble recovery from the Great Depression could become a permanent state for the U.S. economy, because, as he argued, "sick recoveries [....] die in their infancy and depressions [...] feed on themselves and leave a hard and seemingly immovable core of unemployment" (Hansen 1939, p. 4). While the U.S. economy was facing a crisis of woefully inadequate aggregate demand, Hansen's (1939, p. 11) main concern was the lack of sufficiently profitable investment outlets: "It is my growing conviction that the combined effect of the decline in population growth, together with the failure of any really important innovations of a magnitude sufficient to absorb large capital outlays, weighs very heavily as an explanation for the failure of the recent recovery to reach full employment." Hansen warned that without a more rapid advance of technology than in the past, the U.S. economy would be unable to find private investment opportunities adequate to maintain full employment. However, Hansen's worries soon became obsolete as the post-World War II economic order formed itself — and a much more equal income distribution, an expanding middle class and suburbanization, and Cold-War-era 'military Keynesianism' turned his under-consumptionist fears irrelevant. The U.S., and other OECD countries, returned to strong economic growth, (public and private) investment in research and development rose sharply, also as part of Cold War military spending, spurring decades of technological progress and ending the dearth of profitable investment outlets. Hansen's secular stagnation thesis failed to take hold.

But now the wheel of history has turned: Hansen's thesis has made a come-back in (global) macroeconomic policy discourse, chiefly because the 'Great Recession', which followed the Great Financial Crisis of 2008, looked so uncomfortably familiar and similar to what happened during the 1930s. Lawrence Summers $(2013$, 2015) revived Hansen's original idea for the U.S. economy, but Summers did this with a distinctly pre-Keynesian twist. In Summers analysis, an ageing population, heightened income inequality and a large inflow of foreign finance raised savings and created an excess supply in the market for loanable funds, which pushed the equilibrium ('natural') rate of interest down to its zero-lower bound. The outcome is, according to Summers, a structural 
demand deficiency - and stagnation. However, unlike in Hansen's time, when actual output was much lower than potential output, this time around the output gap is surprisingly narrow. Indeed, virtually all empirical studies of both actual and potential growth in the OECD countries show a remarkable slowdown, which started well before the Great Financial Crisis of 2008-09 (Fernald 2014; Ollivaud and Turner 2014; Storm 2017; Kiefer et al. 2019; Fontanari et al. 2019). For the majority of observers, it must have been declining potential growth which forced down the rate of actual (demand-determined) growth, reflecting deep-rooted theoretical beliefs that while demand does affect actual growth, it does not and cannot influence potential growth, which is completely determined by 'demography' (labor force growth) and 'technology' (productivity growth).

Hence, in its modern incarnation, secular stagnation is not so much a matter of a deficiency of demand (as was Hansen's view), but a symptom of deep structural problems on the supply side of the economy (Fernald 2014, 2016; Furman 2015; Gordon 2014, 2015). An ageing labor force and demographic stagnation constitute a first supply-side problem (Aaronson et al. 2014). But the real problem is the alarming steady decline in total-factor-productivity (TFP) growth, the main component of potential output growth. Diminishing TFP growth is taken to reflect a deep-rooted technological torpor, which lowers the returns on investment and hence pushes desired investment spending down too far. This, in turn, is argued to have lowered the growth rates of both potential and actual GDP (Fernald 2016; Gordon 2015). Importantly, the stagnation of potential output growth cannot be attributed to a mismeasurement of productivity growth (Syverson 2016). Thus, the conclusion must be that the U.S. is 'riding on a slow-moving turtle', and 'there is little politicians can do about it', as Robert Gordon (2015, p. 191) expressed it.

This paper, which focuses on the secular stagnation of productivity growth, wishes to cast doubt on the view that the secular stagnation of U.S. growth must be attributed to supply-side factors. ${ }^{1}$ The chapter argues instead that the slowdown in productivity growth reflects a demand (management) crisis, with the 'under-consumption' driven by stagnating real wages, rising inequality and greater job insecurity and polarization. After defining 'potential growth' in Section 2, we scrutinize its main component (total-factor-productivity or TFP growth) using growth

\footnotetext{
1 This paper is based in part on Storm (2017) and presents a structurally revised, updated and shortened formulation of the main arguments made therein.
} 
accounting schemes. We show that the secular decline in TFP growth in the U.S. is driven almost completely by the long-term slowdown of labor productivity growth and/or the secular decline in real wage growth. In the supply-side narrative, fading labor productivity is supposed to have forced down real wage growth. We present alternative, demand-driven, explanations of the productivity growth slowdown, and argue, based on empirical evidence, that the secular stagnation of productivity growth in the U.S. is almost completely caused by demand-side factors, including the secular decrease in real wage growth. The recognition that demand drives productivity growth and potential growth finally forces us to deeply rethink concepts of 'steady-inflation potential growth' and 'output gaps', which are commonly used as anchors for monetary and fiscal policy-making (see Fontanari, Palumbo and Salvatori 2019; Taylor, Foley and Rezai 2019).

\section{Potential output growth and productivity growth}

We start by defining the growth of 'potential output' $x_{P}$ in terms of TFP growth. To do so, let $\ell_{P}$ be potential labor supply (defined in terms of hours of work) and let $\lambda_{P}=x_{P} / \ell_{P}$ denote the level of potential labor productivity per hour of work. By definition, we have:

$$
x_{P}=\lambda_{P} \times \ell_{P}
$$

If we logarithmically differentiate (1) and write in difference-form, we get the following expression in growth rates:

$$
\hat{x}_{P}=\hat{\lambda}_{P}+\hat{\ell}_{P}
$$

where a circumflex indicates an instantaneous growth rate (or a difference in natural logarithms). Potential output growth depends on potential labor productivity growth ('technology') and the growth of potential labor supply ('demography'). Let us concentrate on productivity growth and assume that $\hat{\ell}_{P}=0 .^{2}$ Next, to explain $\hat{\lambda}_{P}$ and following standard growth-accounting practice, we consider this (constant-returns-to-scale) Cobb-Douglas production function:

\footnotetext{
${ }^{2}$ Empirical estimates of U.S. labor force growth during 1948-2015 appear in Table 1.
} 


$$
x=A \ell^{\phi} K^{1-\phi}
$$

where $x$ is output (or real value added at factor cost); $\ell$ is the actual number of hours worked; $K$ is the value of the capital stock (expressed in constant dollars); and A is a scale factor. Exponent $\phi$ is typically assumed to correspond to the observed labor share in income. If one divides both sides of equation (3) by $x^{\phi}$ and then solves for $(x / \ell)$, or productivity per hour of work, one obtains (see Jones 2015):

$$
\lambda=A^{1 / \phi} \kappa^{-(1-\phi) / \phi}
$$

where $\lambda=x / \ell$ is actual labor productivity per hour of work and $\kappa=x / K$ is capital productivity. Writing (4) in growth rates gives this expression for labor productivity growth:

$$
\hat{\lambda}=\left(\frac{1}{\phi}\right) \hat{A}-\left(\frac{1-\phi}{\phi}\right) \hat{\kappa}
$$

where $\hat{A}$ stands for TFP growth. In the steady state of a neoclassical growth model, the capitaloutput ratio must be constant, which means capital productivity is constant $(\hat{\kappa}=0)$. Equation (5) then becomes:

$$
\hat{\lambda}_{P}=\left(\frac{1}{\phi}\right) \times \hat{A}
$$

Potential labor productivity growth depends completely on TFP growth, which is here assumed to be exogenous. When we next substitute (5\#) into (2), we obtain:

$$
\hat{x}_{p}=\left(\frac{1}{\phi}\right) \times \hat{A}
$$

This way, potential output growth can be shown to depends on exogenous TFP growth — which is today's 'decided opinion' (Fernald 2014, 2016; Furman 2015; Gordon 2015) 
Estimates of potential output growth for the U.S. economy (1948-2015), exclusively based on TFP growth as in eq. (2\#), appear in column $(d)$ of Table 1. Estimates of potential growth by the U.S. Congressional Budget Office (CBO), which include TFP growth and labor force growth, appear in column (e). It can be seen that potential growth of the U.S. economy was 3.85\% per year during the period 1948-1972, which then slowed down to 3.1\% per year during 1972-1995, and to $3.05 \%$ per year during the years of the Great Moderation (1995-2008). After 2008, potential growth dropped by one percentage point to $1.5 \%$ per year. Two-thirds of the decline in potential growth between 1948-1972 and 2008-15 must be attributed to the decline in TFP growth — in line with eq. (2\#). What then is this thing called 'TFP growth'? And is it a purely supply-side factor?

\section{Table 1}

Alternative measures of aggregate TFP growth in the U.S., 1948-2015

(average annual growth rate in per cent)

\begin{tabular}{|l|c|c|c|c|c|c|}
\hline & $\begin{array}{c}\text { 'Solow } \\
\text { residual' } \\
\text { eq. }(6 \#)\end{array}$ & $\begin{array}{c}\text { factor } \\
\text { productivity } \\
\text { growth } \\
\text { eq. }(7)\end{array}$ & $\begin{array}{c}\text { total factor } \\
\text { payment } \\
\text { growth } \\
\text { eq. }(10)\end{array}$ & $\begin{array}{c}\text { potential } \\
\text { output } \\
\text { growth } \\
\text { eq. }(2 \#)\end{array}$ & $\begin{array}{c}\text { labor } \\
\text { force } \\
\text { growth }\end{array}$ & $\begin{array}{c}\text { potential } \\
\text { output } \\
\text { growth } \\
(d)+(e)\end{array}$ \\
\hline & $(a)$ & $(b)$ & $(c)$ & $(d)$ & $(e)$ & $(f)$ \\
\hline $1948-1972$ & 1.60 & $1.57(88 \%)$ & 1.57 & 2.68 & 1.17 & 3.85 \\
\hline $1972-1995$ & 1.06 & $1.04(80 \%)$ & 1.04 & 1.75 & 1.35 & 3.10 \\
\hline $1995-2008$ & 1.35 & $1.34(85 \%)$ & 1.34 & 2.28 & 0.77 & 3.05 \\
\hline $2008-2015$ & 0.73 & $0.72(73 \%)$ & 0.73 & 1.26 & 0.21 & 1.47 \\
\hline $1948-2015$ & 1.27 & $1.25(84 \%)$ & 1.26 & 2.14 & 1.15 & 3.29 \\
\hline
\end{tabular}

Source: Storm (2017); estimates in columns (a) to $(d)$ are based on Bureau of Economic Analysis data. Estimates of labor force growth are derived as the difference between column $(f)$ and $(d)$. Estimates of potential output growth in column $(f)$ are based on data on Real Potential Gross Domestic Product by the U.S. Congressional Budget Office (available at: https://alfred.stlouisfed.org).

Notes: The numbers in parentheses in column $(b)$ give the percentages of weighted factorproductivity growth explained by labor productivity growth as per equation (7). 


\section{Table 2}

Distributional shifts associated with aggregate U.S. TFP growth, 1948-2015

\begin{tabular}{|l|c|c|c|c|c|c|c|c|}
\hline & $\phi$ & $\hat{w}$ & $\hat{\lambda}$ & $\phi(\hat{w}-\hat{\lambda})$ & $1-\phi$ & $\hat{r}$ & $\hat{\kappa}$ & $(1-\phi)(\hat{r}-\hat{\kappa})$ \\
\hline & $(1)$ & $(2)$ & $(3)$ & $(4)$ & $(5)$ & $(6)$ & $(7)$ & $(8)$ \\
\hline $1948-1972$ & 0.60 & 2.68 & 2.32 & 0.21 & 0.40 & -0.06 & 0.46 & -0.21 \\
\hline $1972-1995$ & 0.60 & 1.15 & 1.38 & -0.14 & 0.40 & 0.88 & 0.52 & 0.14 \\
\hline $1995-2008$ & 0.59 & 1.92 & 1.92 & 0.00 & 0.41 & 0.49 & 0.49 & 0.00 \\
\hline $2008-2015$ & 0.57 & 0.58 & 0.91 & -0.20 & 0.43 & 0.93 & 0.46 & 0.20 \\
\hline $1948-2015$ & 0.60 & 1.80 & 1.78 & 0.01 & 0.40 & 0.46 & 0.49 & -0.01 \\
\hline
\end{tabular}

Source: Storm (2017).

Notes: $\phi=$ the period-average labor income share; $\hat{w}=$ average annual real wage growth (per hour); $\hat{\lambda}=$ average annual hourly labor productivity growth; $\hat{r}=$ average annual real profit rate growth; $\hat{\kappa}=$ average annual capital productivity growth; $(\hat{w}-\hat{\lambda})=$ average annual (real) wage share growth; and $(\hat{r}-\hat{\kappa})=$ average annual (real) profit share growth.

\section{Total-factor-productivity (TFP) growth: Solow variations}

Ever since Robert Solow (1957) began cranking the numbers more than six decades ago, TFP growth has been treated as a non-observable variable that can only be quantified as an 'unexplained residual' in a growth-accounting scheme (Jones 2015; Furman 2015). Specifically, if we express production function (3) in growth rates, we get:

$$
\hat{x}=\hat{A}+\phi \hat{\ell}+(1-\phi) \widehat{K}
$$

from which TFP growth $(\hat{A})$ can be determined as a residual:

$$
\hat{A}=\hat{x}-\phi \hat{\ell}-(1-\phi) \widehat{K}
$$


Eq. (6\#) defines TFP growth as the unexplained 'Solow residual'. Estimates of the 'Solow residual' for the U.S. economy (1948-2015) appear in column (a) of Table 1. Aggregate TFP growth in the U.S. economy declined - from $1.6 \%$ per year during the 1950 s and 1960 s to $0.73 \%$ per annum during 2008-15. And future TFP growth in the U.S. looks set to get worse: Fernald's (2016) modal forecast for U.S. TFP growth during 2016-2023/26 is in the range of $0.41-0.55 \%$ per year.

Textbook convention interprets TFP growth $(\hat{A})$ as an indicator of Hicks-neutral disembodied technological progress. TFP growth is a key diagnostic for policy-making, because it "tells us how efficiently and intensely inputs are used" and "this is easily mapped to innovation of the technological and managerial sorts" (Furman 2015, p. 2). To Furman (2015) TFP growth measures "pure innovation". Waning TFP growth must therefore mean that the cumulative growth effects of the latest innovations (in microprocessors \& computer chips, artificial intelligence (AI), robotics, materials and biotechnology) is weaker than those of past technologies (Gordon 2015; Fernald 2014; IMF 2015; Jones 2015). This is surprising, perhaps, and it reminds one of Robert Solow's well-known aphorism that "you can see the computer age everywhere but in the productivity statistics." Most observers agree that waning TFP growth must be therefore be due to the fact that institutional rigidities in and regulation of labor and product markets limit the ability of firms and markets to restructure and reorganize to benefit from ICT, robotics and AI (Fernald 2016).

If so, remedying this situation will require a supply-side policy agenda - which should include, following Furman (2015), further labor market deregulation, business tax reforms and more public investment in infrastructure, education and RD\&D (Gordon 2015; Fernald 2016). However, even if we accept textbook convention and treat TFP growth as an indicator of Hicksneutral disembodied technological progress, eq. (6\#) lacks any deeper analytical insight into the structural determinants of such technological progress. Moses Abramovitz (1956) called the Solow residual a "measure of our ignorance", and while the search for dependable and robust determinants of TFP growth has consumed the research efforts of at least two generations of (growth-accounting) economists, Abramovitz's conclusion still rings true. Summing up the bottom line of decades of research, Furman (2015, p. 2) concludes "a rigorous conceptual understanding of that [residual] continues to elude economists even today". This is problematic, because TFP growth is supposed 
to be the main determinant of potential output growth. Fortunately, TFP growth is less of a mystery than Furman and others think, because it can be measured directly in two different ways - using real observable data.

The first approach to direct measurement of TFP growth is as follows. Using definitions $\hat{\lambda}=\hat{x}-\hat{\ell}$ and $\hat{\kappa}=\hat{x}-\widehat{K}$, TFP growth in $e q$. (6\#) can be rewritten as:

$$
\hat{A}=\phi \hat{\lambda}+(1-\phi) \hat{\kappa}
$$

Equation (7) is rather unsurprising, as it defines $\hat{A}$ as the weighted average of the growth rates of labor and capital productivities. Estimates of TFP growth for the U.S. (1948-2015), based on eq. (7), appear in column $(b)$ of Table 1. It is noteworthy that labor productivity growth 'explains' around $85 \%$ of TFP growth and is a quantitatively far more important determinant of TFP growth than capital productivity growth. This finding is consistent with one of Nicholas Kaldor's (1961) stylized facts on growth, namely that the capital-output ratio does not exhibit a systematic trend in the long run — which means $\hat{\kappa}=0$. If Kaldor's stylized fact holds true, eq. (7) simplifies to: $\hat{A}=$ $\phi \hat{\lambda}$. Note that TFP growth is now no longer exogenous (unlike in the 'Solow residual' approach), as it is causally determined by labor productivity growth. Crucially, the direction of causality in $e q$. (7) is the opposite of that in eq. (5\#). Indeed, if labor productivity growth is the only structural determinant of TFP growth in the long run, it follows not just that $\hat{x}_{P}=\hat{\lambda}_{P}=\left(\frac{1}{\phi}\right) \times \hat{A}=\hat{\lambda}$, but also that TFP growth adds no additional analytical insight and can be dropped from the economist's growth-accounting toolkit without consequence.

The second approach is the so-called 'dual approach' (Simon and Levy 1963; Jorgenson and Griliches 1967; Shaikh 1974; Barro 1999; Rada and Taylor 2006; Felipe and McCombie 2012). It starts off from the NIPA accounting identity that real GDP at factor cost is the sum of wage income and capital income:

$$
x=w \ell+r K
$$


where $w$ is the real wage rate per hour of work and $r$ is the real profit rate on the capital stock. This condition must hold if all the GDP is attributed to one of the factors. Dividing (8) by $x$, we get: $1=\left(\frac{w \ell}{x}\right)+\left(\frac{r K}{x}\right)=\phi+(1-\phi)$, where $\phi$ is the observed labor share in income at any time and $(1-\phi)$ is the observed capital share. Eq. (8) can be written in terms of growth rates as follows:

$$
\hat{x}=[\phi \widehat{w}+(1-\phi) \hat{r}]+\phi \hat{\ell}+(1-\phi) \widehat{K}
$$

$E q$. (9) remains an accounting identity, because its derivation uses only the NIPA ${ }^{3}$ condition $x=w L+r K$. We must note that (9) holds true even if the aggregate production function does not exist (Felipe and McCombie 2012). Eq. (9) is functionally equivalent to (6) - but the latter must be read as a wrongly specified representation of the former (Felipe and McCombie 2012). This isomorphism between production function (6) and NIPA value-added accounting identity (9) does not permit us to make any direct inference about 'aggregate technological progress'. "Solow's measure of technical change," as Shaikh (1974, p. 118) already noted, "is merely a weighted average of the growth rates of the wage $w$ and rate of profit $r$." Hence, the aggregate production function, as Shaikh concludes, is based on 'a law of algebra, not a law of production'. Empirically, the only valid interpretation of TFP growth is, therefore, in terms of 'total-factor-payment growth':

$$
\hat{A}=\phi \widehat{w}+(1-\phi) \hat{r}
$$

Estimates of TFP growth for the U.S. (1948-2015), based on eq. (10), appear in column (c) of Table 1. Measured TFP growth is declining over time and based on eq. (10) this reflects a secular decline in the growth rates of real wages and real profits - as is shown in Table 2. Average annual real wage growth in the U.S. declined from $2.68 \%$ during $1948-1972$ to $0.58 \%$ during $2008-2015$ and this lowered annual TFP growth by 1.3 percentage points (using the values for $\phi$ given in Table 2). The secular decline in real wage growth is, in other words, another key factor playing a role in the fading of TFP growth and potential output growth. This inference is confirmed by the econometric analysis by Kiefer, Mendieta-Muñoz, Rada and von Arnim (2019), who find that the

${ }^{3}$ NIPA stands for National Income and Product Accounts.

${ }^{4}$ Given this isomorphism, statistically estimating (3) means that one is estimating an identity. This explains why the empirical fit (measured by $\bar{R}^{2}$ ) is generally exceptionally good for production functions (Felipe and McCombie 2012). 
secular stagnation of potential growth of the U.S. economy during 1948-2016 is closely associated with the long-term decline in the wage share.

However, as a matter of accounting, the 'primal' estimate of TFP growth in eq. (7) must equal the 'dual' estimate based on the share-weighted growth of factor prices in eq. (10) - and it must also equal the 'Solow residual' of eq. (6\#). Indeed, the estimated TFP growth rates are the same across definitions (see Table 1) — and in all cases, the evidence points to a secular stagnation of productivity growth and hence of potential growth.

The neoclassical intuition for the dual of eq. (10) is, as Barro (1999) explains, that rising factor prices can be sustained only if factor productivities in eq. (7) are increasing in tandem. In the neoclassical steady state, and assuming 'perfect competition' in product and factor markets, real wage (profit) growth must converge to labor (capital) productivity growth, or $\widehat{w}=\hat{\lambda}$ and $\widehat{r}=$ $\widehat{\kappa}$. In the hypothetical case of a 'perfectly competitive' economy, the primal and dual estimates must fully coincide. However, there is nothing in the NIPA accounting to ensure that these conditions $(\widehat{w}=\hat{\lambda}$ and $\widehat{r}=\widehat{\kappa}$ ) do hold - empirically, we find that $\widehat{w} \neq \hat{\lambda}$ and $\widehat{r} \neq \widehat{\kappa}$ (see the historical evidence for the U.S. in Table 2), and hence (7) and (10) do not coincide (Storm 2017). The most we can infer from the above is this. Subtracting eq. (7) from eq. (10), we get:

$$
\phi(\widehat{w}-\hat{\lambda})+(1-\phi)(\hat{r}-\hat{\kappa})=0
$$

which is, as is pointed out by Rada and Taylor (2006, p. 488), "a cost-side restriction on observed growth rates of average productivities and factor payments." Eq. (11) states that, for any given rate of TFP growth, the weighted sum of wage share growth $(\widehat{w}-\hat{\lambda})$ and profit share growth $(\widehat{r}-\widehat{\kappa})$ must be zero - which underscores the zero-sum distributive conflict between workers and profitrecipients underlying TFP growth.

Let me summarize the discussion so far. Using simple growth accounting schemes, we have identified three separate accounts of the secular stagnation of potential output growth:

- a first narrative in which the declining 'Solow residual' signals a lack of innovation and general technological malaise on the supply-side of the economy; 
- a second explanation centered on the slowdown of (especially) labor productivity growth;

- and a third account centered on stagnating real wage growth as a factor playing the most prominent role in declining TFP growth.

How can these three explanations be aligned into one single, consistent explanation? The dominant view, illustrated in Figure 1, is that the technological torpor captured by the exogenous decline in TFP growth $(\hat{A})$ leads to lower labor productivity growth $(\hat{\lambda})$, as in eq. $(5 \#)$, which in turn forces down real wage growth. That is, in line with the marginal productivity theory of income distribution, neoclassical 'intuition' holds that real wage growth 'follows' exogenous productivity growth, because profit-maximizing firms will hire workers up until the point at which the marginal productivity of the final worker hired is equal to the real wage rate (Barro 1999; Jones 2015). There is, in this view, nothing surprising about the co-occurrence of a shrinking 'Solow residual', declining labor productivity growth and decreasing real wage growth, as the technological stagnation forces profit-maximizing firms to lower their real wage growth offer. In this view, the secular stagnation of productivity growth exclusively has supply-side origins. This is the decided opinion today. But, as John Stuart Mill observed long ago, "the fatal tendency of mankind to leave off thinking about a thing when it is no longer doubtful, is the cause of half their errors" and Mill appositely warned about the "deep slumber of a decided opinion".

\section{Figure 1}

The economics of secular stagnation:

the supply-side view

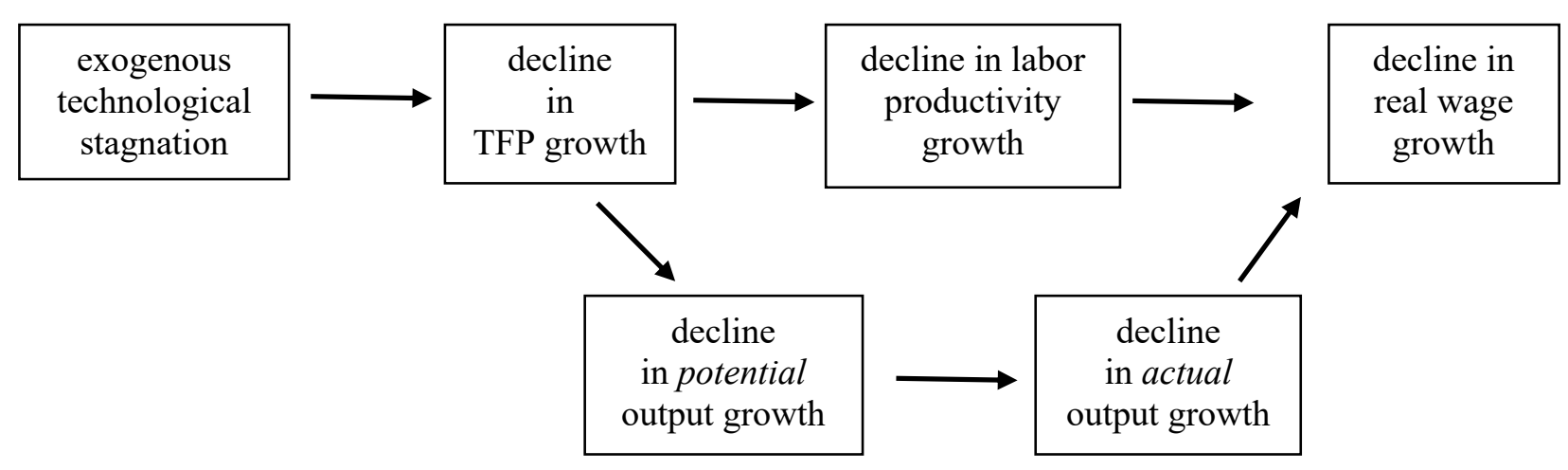




\section{Bringing demand in from the cold}

The 'supply-side intuition' does not allow for any influence of demand factors on the secular decline in productivity growth and blames the decline in potential growth on the slowdown of exogenous technological progress. However, the problem with this simple 'intuition' is that it is wrong. There are sound theoretical reasons, and there is robust empirical evidence, to blame (a substantial part of) the long-run decline in productivity growth on stalling demand growth (Storm 2017; Girardi, Paternesi Meloni and Stirati 2018; Fontanari et al. 2019). This goes against a deeprooted theoretical belief system which maintains that long-run trend growth, which is argued to be determined by the supply-side factors 'technology' and 'demography', can be completely separated from short-run fluctuations of actual growth around this trend, which are held to be due to changes in demand. It is this belief system - that 'Keynes' holds only for the short run, whereas the inexorable supply-side factors 'demography' and 'technology' govern the long-run, and on which macroeconomics has built its notions of 'potential output' and 'output gaps', which are widely employed to anchor macro-economic, and especially monetary, policy (Fatás 2018) — which has to be radically rethought (Girardi et al. 2018; Fontanari et al. 2019).

A first theoretical channel through which a shortage of demand affects labor productivity growth is through a slower accumulation of capital. To see this, consider eq. (3). If we divide both sides of the equation by total hours worked $(\ell)$, rearrange and express in growth rates, we obtain this expression for $\hat{\lambda}$ :

$$
\hat{\lambda}=\hat{A}+(1-\phi)(\widehat{K}-\hat{\ell})
$$

A decline in capital-intensity growth $(\widehat{K}-\widehat{\ell})$ reduces labor productivity growth. Capital intensity growth in the U.S. decreased from $1.86 \%$ per annum during the 1950 s and 1960 s to $0.86 \%$ per year during 1972-95 and further to 0.45\% during 2008-15 (Table 3). Using eq. (12), we find that sixty percent of the drop in U.S. labor productivity growth from $2.32 \%$ per year during $1948-72$ to $0.91 \%$ per year during 2008-15 must be attributed to the drop in U.S. capital intensity growth. Capital stock growth $\widehat{K}$ depends on business investment - and business investment is overwhelmingly dependent on (expected) aggregate demand and (expected) profitability (Cynamon and Fazzari 
2017). ${ }^{5}$ Recent econometric findings on U.S. business investment (during 1983 Q4 and 2016Q4) by IMF economists Kopp, Leigh, Mursula and Tambunlertchai (2019, p. 4) confirm this conclusion. The authors write that there "appears to be little unexplained component of business investment beyond the expected demand effect. Other factors, such as reductions in the cost of capital, thus appear to have played a relatively minor role." Accordingly, a structural decline in demand growth depresses labor productivity growth - through dithering business investment and a decline in capital deepening, a relationship known in the literature as the Kaldor-Verdoorn relation (Storm and Naastepad 2012). As a result, TFP growth must decline as well (via eq. (7)), and potential output growth is forced down - an empirically plausible story, but one which is fundamentally at odds with 'decided opinion'.

We can uncover the same theoretical channel, through which a demand shortage contributed to the secular stagnation of potential growth, in one more way. Let us assume that $\chi=1 / \kappa$ is the constant capital-to-potential-output ratio. We define potential output as $x^{*}=K / \chi$ and capacity utilization as $u=x / x^{*}$. It then follows that actual output $x=u K / \chi$. Writing in (instantaneous) growth rates we get:

$$
\hat{x}=\hat{u}+\widehat{K}
$$

Actual output growth in eq. (13) depends on the growth of the capital stock (which reflects potential growth) and the growth of capacity utilization which mirrors cyclical demand factors which may cause actual growth to deviate from potential growth. Combining (13) and (6) and rearranging, TFP growth becomes:

5 In the New Keynesian account of Summers (2015) business investment depends on the rate of interest or the cost of capital. With higher savings (due to ageing and a supposed global savings glut), the interest rate came down in the market for loanable funds, which in turn should have raised investment. But once the interest rate got stuck at the zero-lower bound, excess savings could no longer be channelled into higher investment — and stagnation was the outcome. The problems with Summers' argument are that $(i)$ U.S. business investment is not very sensitive to changes in the cost of capital, but overwhelmingly depends on (expected) demand; and (ii) the market for loanable funds does not exist, as money-creating commercial banks can and do originate credit to finance investment irrespective of whether they have the savings deposits beforehand. 


$$
\hat{A}=\hat{u}+\phi(\widehat{K}-\hat{\ell})
$$

The key diagnostic 'TFP growth' now directly depends on capital deepening and the growth of utilization. Equation (14) could be read as a variant of the AK-model of endogenous growth, since TFP growth rises with capital stock growth, but, unlike in new growth theory, here we do not need to invoke microeconomic (knowledge) externalities to justify it, but only have to assume that $\chi$ is constant. Table 3 presents evidence on eq. (14) for the U.S. economy (1948-2015). The contribution to TFP growth of capital deepening declined from 1.1\% per year during 1948-72 to $0.84 \% \%$ per year during $1995-2008$ - a decline of 0.26 percentage points which fully explains the fall in TFP growth from $1.6 \%$ per year in the first period to $1.35 \%$ per annum during the second period. Likewise, the decline in TFP growth by 0.62 percentage points between 1995-2008 and 2008-15 is almost completely due to declining capital-intensity growth, which in turn is caused by a sharp, crisis-induced, drop in the investment-GDP ratio (see the note to Table 3; Ollivaud et al. 2016; Storm 2017; Kopp et al. 2019).

If we next define $i=\Delta K / x$ as the investment-GDP ratio, then it follows that $i=\frac{\Delta K}{K} \times \frac{K}{x^{*}} \times \frac{x^{*}}{\chi}=\widehat{K} \chi u^{-1}$. This gives us the following expression for $\widehat{K}$ :

$$
\widehat{K}=\frac{u \times i}{\chi}
$$

A higher investment-to-GDP ratio leads to faster capital stock growth - at constant capacity utilization. Since empirically investment is usually completely dominated by 'accelerator effects' operating through aggregate demand (Kopp et al. 2019), it follows from (14) and (15) that a structural decline in demand growth depresses TFP growth - through stagnating business investment, a decline in capital deepening and/or declining capacity utilization. As a result, the growth rate of potential output must be low - this causal chain is illustrated in Figure 2. Crucially, once the demand deficiency has lowered potential output growth, this means a low "speed limit" for actual growth, as inflation-adverse monetary policymakers, convinced that low TFP growth is due to a technological malaise, will keep actual growth close to sluggish potential growth. This is illustrated in Figure 2 by the dashed arrow from 'potential output growth' to a 'structural shortage of aggregate demand': because the 'observed' output gap is small (which makes the risk of inflation 
look relatively large), monetary policy authorities will be inclined to step on the brakes and raise interest rates in response to a revival of actual growth - nipping the recovery in the bud and creating a 'sick recovery' which 'dies in its infancy'. Stagnation, while being avoidable because potential growth can be raised by higher investment and demand, becomes a self-fulfilling process (Storm 2017; Fontanari et al. 2019).

\section{Figure 2}

The economics of secular stagnation:

the demand-side view

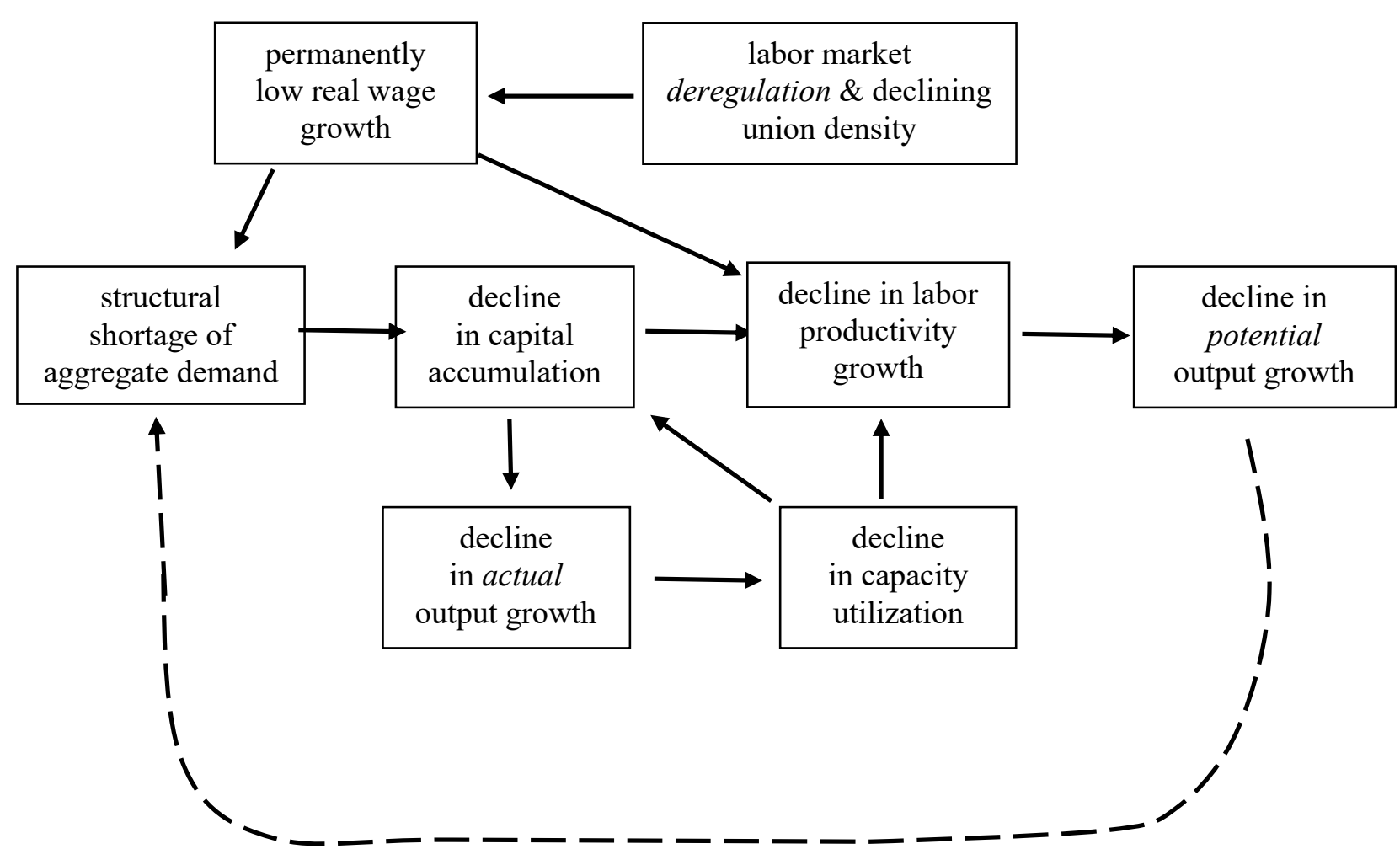




\section{Table 3}

TFP growth, capital deepening and utilization, 1948-2015

(average annual growth rates in per cent)

\begin{tabular}{|l|c|c|c|c|c|}
\hline contribution of: & $1948-72$ & $1972-95$ & $1995-2008$ & $2008-15$ & $1948-2015$ \\
\hline capital deepening & 1.10 & 0.52 & 0.84 & 0.25 & 0.77 \\
\hline capacity utilization & 0.48 & 0.53 & 0.50 & 0.47 & 0.50 \\
\hline TFP growth & 1.58 & 1.05 & 1.34 & 0.72 & 1.26 \\
\hline memo items: & & & & & \\
\hline - Solow residual & 1.60 & 1.06 & 1.35 & 0.73 & 1.27 \\
\hline - capital-intensity growth & 1.86 & 0.86 & 1.43 & 0.45 & 1.29 \\
\hline
\end{tabular}

Source: Storm (2017).

Note: The Table is based on equation (14). In equation (15), TFP growth is a function of the ratio of gross domestic investment to GDP. The OLS regression result for 1948-2015 is:

TFP growth $=-3.42+0.20($ Investment/GDP $)+1.88$ D2010 $\quad \bar{R}^{2}=0.09 ; n=68$

$$
(2.50)^{* *}(3.32)^{* * *} \quad(8.02)^{* * *}
$$

D2010 is a dummy for the year 2010. The decline in the U.S. investment-GDP ratio from $23.9 \%$ on average per year during $1995-2008$ to $20.7 \%$ per year during $2008-15$ 'explains' more than $80 \%$ of the post-2008 decline in TFP growth in the U.S. (Ollivaud et al. (2016) present similar findings for the OECD). The same holds true in the long run. The slowdown of capital accumulation from $24.4 \%$ of GDP on average per year during 1948-1972 to $22.8 \%$ of GDP on average per year during 1995 2015 is found to 'explain' more than $60 \%$ of the long-run decline in U.S. TFP growth.

\section{Wage growth as a determinant of productivity growth}

In the supply-side explanation of secular stagnation (of Figure 1), productivity growth is treated as an exogenous variable, and if and when it declines, real wage growth is forced down - because profit-maximizing firms will not allow unit labor costs to increase. What is neglected in this narrative, however, is that causality may run in the opposite direction as well: indeed, real wage growth is found to be a major determinant of productivity growth (Gordon 1987, 2015; Foley and Michl 1999; Marquetti 2004; Basu 2010; Storm and Naastepad 2012). Theoretically, the influence of real wage growth on labor productivity growth has been variously explained in terms of 'induced technical change' (Hicks 1932; Funk 2002; Brugger and Gehrke 2017), 'Marx-biased technical change' (Foley and Michl 1999; Basu 2009), or 'directed technical change' (Acemoglu 2002) _ 
but the key mechanism is this: rising real wages, as in the U.S. economy during the period 19481972 (Table 2), provide an incentive for firms to invest in labor-saving machinery and productivity growth surges as a result; but when wage growth is low, as in the U.S. during 1972-2015 (Table 2), businesses have little incentive to invest in the modernization of their capital stock and productivity growth falters.

Seen this way, labor productivity growth is endogenous and (at least partly) determined by real wage growth. If so, then the secular stagnation of productivity growth in the U.S. economy must be attributed at least partly to the long-term decline in the growth rate of U.S. hourly real wages. This is illustrated in the mnemonic of Figure 2 by the arrow from 'permanently low real wage growth' to 'decline in labor productivity growth'. The decline in real wage growth in turn is strongly associated with the post-1980 reorientation in macroeconomic policy, away from full employment and towards low and stable inflation, which paved the way for labor market deregulation, a scaling down of social protection, a lowering of the reservation wage of workers, and a general weakening of the wage bargaining power of unions (Storm and Naastepad 2012). The recent rise in persons 'working in alternative work arrangements' in the U.S. (Katz and Krueger 2016) is merely the culmination of this earlier trend. To empirically illustrate this point, Figure 3 shows that there is a statistically significant (at 1\%) positive long-run relation between the degree of unionization and real wage growth in the U.S. (1948-2015). The association is remarkably strong: all by itself, the secular decline in unionization 'explains' about two-thirds of the long-term fall in real wage growth - which minimally suggests that domestic regulatory changes leading to greater job and income insecurity have contributed to real wage restraint.

However, real wage stagnation generates additional damage to potential output growth, as is illustrated in Figure 2. Stagnant real wage growth adds to the aggregate demand shortage, which lowers capacity utilization and capital stock growth in eq. (15), or alternatively, it reduces utilization and TFP growth in eq. (14). Either way, potential growth gets hurt - and economic growth slows down. The recognition that real wage growth is a major driver of productivity growth holds an important insight for macroeconomic policy, as Robert Gordon (1987, pp. 154-155) explains: 
“... a stimulus to aggregate demand provides not only the direct benefit of raising output and employment, but also the indirect benefit of raising the real wage and creating substitution away from labor that boosts productivity [....] With this dual benefit obtainable from demand expansion, the case against demand stimulation must rest on convincing evidence that such policies would create an unacceptable acceleration of inflation."

Higher wage growth may raise inflation considerably less than expected, in other words, because the rate of potential growth goes up in response to the increases in productivity, demand and actual output induced by the extra wage growth (see Figure 2; Storm and Naastepad 2012; Storm 2018; Girardi et al. 2018; Fontanari et al. 2019). If so, the reverse holds true as well: sluggish business investment in the U.S. has been a key factor behind the stagnation of TFP growth and has also been responsible for propagating hysteresis-like adverse consequences for TFP and potential output after 2008 (see Hall 2014; Ollivaud et al. 2016; Fazzari et al. 2017; Cynamon and Fazzari 2017; Girardi et al. 2018). This conclusion only becomes stronger once we acknowledge the 'cumulative causation' at work: sluggish investment weakens aggregate demand and this, in turn, weakens accumulation through the 'accelerator effect' — which was Nicholas Kaldor's argument — as well as real wage growth, which reduces the rate of labor-saving technological progress (as argued here). Both ways, cyclical and/or structural demand shortfalls must carry over into lower growth of potential output.

\section{Figure 3}

Stagnating hourly real wage growth and declining union density:

U.S. economy, 1948-2015 


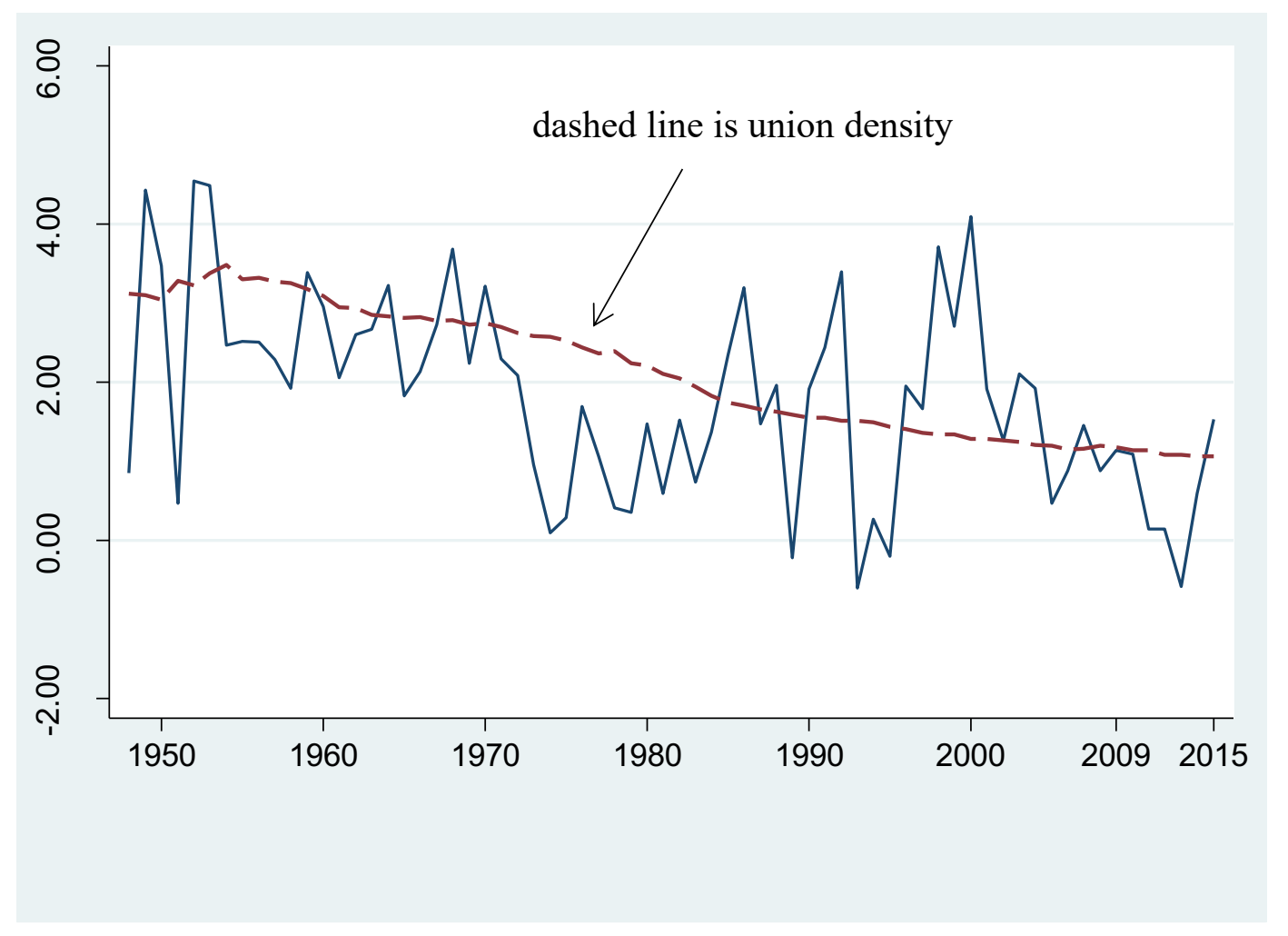

Source: Storm (2017).

Notes: The dashed line represents national union density (defined in terms of ten percentage points), which declines from 3 (or about $30 \%$ ) in the early 1950 s to 1.1 (or 11\%) in 2015 . Hourly real wage growth and union density are very strongly correlated (see Storm 2017).

\section{Conclusion: weak demand growth pulls down potential output growth}

The theoretical arguments and empirical evidence presented in this paper make the case for demand-led secular stagnation in the U.S. economy since the early 1980s. Obviously, no single chart or empirical test "proves" the case. Rather the case rests on a historical analysis of multiple pieces of evidence, which all point in the same direction. The present theoretical analysis and the evidence, when taken together, do lead to an unmistakable conclusion: demand is leading supply, in the short as well as in the long run - which is an insight that runs counter to today's 'decided opinion'. The important dynamic macro channels through which demand growth influences potential output growth, listed in Figure 2, deserve more attention in research. ${ }^{6}$ After all, it is

6 Key studies on these channels include Storm and Naastepad (2012), DeLong and Summers (2012), Hall (2014), Fazzari et al. (2017), Storm (2017), Girardi et al. (2018), Taylor et al. (2019) and Fontanari et al. (2019). 
through these channels that stagnant business investment leads to a slower adoption of new technologies, a more limited space for learning by doing and exploiting economies of scale, and as Hansen rightly argued - a discouragement to (demand-pull) initiatives to uncover further possibilities for innovation.

Recognizing the importance of demand growth to long-run growth has profound and radically upsetting consequences for macro policy-making. Indeed, the all-too-neat separation between a 'Keynesian' short run and 'supply-determined' potential growth in the long run breaks down - and so do standard notions and measurements of 'potential' output growth and 'output gaps' (Fontanari et al. 2019). What must be recognized is that structurally weak demand growth forces down potential growth, whereas faster demand growth, supported by more expansionary, full-employment oriented fiscal and monetary policies, raises productivity growth and potential output. Conventional (supply-side) measures of potential output which ignore the dynamic demand-side channels, systematically overemphasize the 'inflation barrier' and methodically underestimate the margins for expansion of actual output (Fontanari et al. 2019) and thereby legitimate a structural deflationary bias in macro policy (Storm and Naastepad 2012; Girardi et al. 2018; Storm 2017). What is not recognized is that higher demand may gradually remove the scarcities and bottlenecks which in the short run might create inflation pressures. To illustrate this important point: as shown by a model analysis of Fazzari et al. (2017), it is entirely plausible for changes in demand growth from something like $1 \%$ to $3 \%$ to be accommodated by endogenous adjustments of supply, without generating additional inflation. Hence, we need new, more realistic and less biased measures of potential output growth, which take the dynamic impacts of demand on potential growth into account and remove all the unwarranted deflationary policy biases of existing approaches.

The unwarranted deflationary bias shows up in constant needless fiscal austerity, the abandonment of demand management in order to maintain full employment, overly restrictive monetary policy, and real wage stagnation (and rising income inequality), which jointly explain most, if not all, of the secular stagnation (as has been argued here). Real wage restraint directly reduces labor-saving technological progress and productivity growth. Moreover, when the top income-earners ('the $1 \%$ ') are allowed to capture most of the growth, the economy's central 
function to recycle income back into demand is deeply compromised. As real incomes stagnate for the large majority of households, weak aggregate demand in turn feeds into sluggish business investment and a decline in capital deepening and ultimately into a slowing down of productivity growth and potential growth (Figure 2). Stagnation is a sad instance of iatrogenesis, as it is a pathology caused by the exact economists whose task it is to improve the economy's health. To do better, we must look more deeply at shifting social norms that affect wage setting and allow higher inequality, and think creatively about how income growth can be restored across the distribution. Understanding these issues is difficult; designing effective macro policies to keep up demand growth in line with full employment and with potential growth may be even harder. But one thing is clear: unless we discard 'decided opinion' that secular stagnation is an exclusively supply-side phenomenon and recognize that demand drives growth 'all the way' (see Taylor et al. 2019), macro policy will retain its deflationary biases and secular stagnation remains the 'normal'. Hansen had it right after all. 


\section{References}

Aaronson, S., T. Cajner, B. Fallick, F. Galbis-Reig, C. Smith, and W. Wascher. 2014. "Labor force participation: recent developments and future prospects." Brookings Papers on Economic Activity 2014: 261-271

Abramovitz, M. 1956. "Resource and output trends in the United States since 1870." NBER Occasional Paper 52.

Acemoglu, D. 2002. "Directed technical change." The Review of Economic Studies 69 (4): 781809.

Ball, L.M. 2014. "Long-term damage from the Great Recession in OECD countries." NBER Working Paper No. 20185.

Barro, R. J. 1999. "Notes on growth accounting." Journal of Economic Growth 4 (1): 119-137.

Basu, D. 2010. "Marx-biased technical change and the neoclassical view of income distribution." Metroeconomica 61 (4): 593-620.

Brugger, F. and C. Gehrke. 2017. "The neoclassical approach to induced technical change: from Hicks to Acemoglu." Metroeconomica 68 (4): 730-776.

Cynamon, B.Z. and S.M. Fazzari. 2017. Secular demand stagnation in the $21^{\text {st }}$ century U.S. economy." Paper presented at the INET Secular Stagnation Conference. Available at: https://www.ineteconomics.org/uploads/papers/Cynamon-Fazzari-Secular-Demand-

\section{Stagnation-in-the-21st-Century-U.S.-Economy.pdf}

DeLong, J.B. and L.H. Summers. 2012. "Fiscal policy in a depressed economy." Brookings Papers on Economic Activity. Spring: 233-74.

Fatás, A. 2018. "Fiscal policy, potential output and the shifting goalposts." CEPR Discussion Paper No. DP13149.

Fazzari, S.M., P.E. Ferri and A. Variato. 2018. "Demand-led growth and accommodating supply." Available at: https://papers.ssrn.com/sol3/papers.cfm?abstract id=3108711.

Felipe, J. and J.S.L. McCombie. 2012. "Aggregate production functions and the accounting identity critique: further reflections on Temple's criticisms and misunderstandings." Working Paper No. 718, Levy Economics Institute of Bard College.

Fernald, J.G. 2014. "Productivity and potential output before, during, and after the Great Recession.” In NBER Macroeconomics Annual 2014, Vol. 29. University of Chicago Press. 
Fernald, J.G. 2016. "Reassessing longer-run U.S. growth: how low?” Federal Reserve Bank of San Francisco Working Paper 2016-18.

Foley, D. K. and T.R. Michl. 1999. Growth and Distribution. Cambridge, Mass.: Harvard University Press.

Fontanari, C., A. Palumbo and C. Salvatori. 2019. "Potential output in theory and practice: a revision and update of Okun's original method." INET Working Paper No. 93. New York: Institute for New Economic Thinking https://www.ineteconomics.org/research/researchpapers/demand-determined-potential-output-a-revision-and-update-of-okuns-originalmethod

Funk, P. 2002. “Induced innovation revisited.” Economica 69 (273): 155-171.

Furman, J. 2015. "Productivity growth in the advanced economies: the past, the present, and lessons for the future.” Remarks at Peterson Institute for International Economics, July 9.

Girardi, D., W. Paternesi Meloni and A. Stirati. 2018. "Persistent effects of autonomous demand expansions." INET Working Paper No. 70. New York: Institute for New Economic Thinking. https://www.ineteconomics.org/research/research-papers/persistent-effects-ofautonomous-demand-expansions

Gordon, R.J. 1987. "Productivity, wages, and prices inside and outside of manufacturing in the U.S., Japan, and Europe.” European Economic Review 31 (3): 685-733.

Gordon, R.J. 2014. "U.S. economic growth is over: the short run meets the long run.” In Growth, Convergence and Income Distribution: The Road from the Brisbane G-20 Summit, Brookings, Think Tank 20, pp. 185-192.

Gordon, R.J. 2015. "Secular stagnation: a supply-side view." American Economic Review 105 (5): 54-59.

Hall, R.E. 2014. "Quantifying the lasting harm to the U.S. economy from the financial crisis." NBER Macroeconomics Annual 2014.

Hansen, A. 1939. "Economic progress and declining population growth." American Economic Review 29 (1): 1-15.

Hicks, J.R. 1932. The Theory of Wages. London: MacMillan.

IMF. 2015. "The new normal: a sector-level perspective on productivity trends in advanced economies." IMF Staff Discussion Notes No. 15/3. 
Jones, C.I. 2015. "The facts of economic growth." NBER Working Papers 21142. Available at: http://web.stanford.edu/ chadj/facts.pdf

Jorgenson D. W. and Z. Griliches. 1967. "The explanation of productivity change." Review of Economic Studies 34 (99): 249-283.

Kaldor, N. 1961. "Capital Accumulation and Economic Growth." in F.A. Lutz and D.C. Hague (Eds.) The Theory of Capital. New York: St. Martin's Press, 177-222.

Katz, L.F. and A.B. Krueger. 2016. "The rise and nature of alternative work arrangements in the United States, 1995-2015.” https://krueger.princeton.edu/sites/default/files/ akrueger/files/katz krueger_cws__march_29_20165.pdf

Kopp, E., D. Leigh, S. Mursula and S. Tambunlertchai. 2019. "U.S. Investment since the Tax Cuts and Jobs Act of 2017." IMF Working Paper No. WP/19/120. Washington, DC: IMF.

Kiefer, D., I. Mendieta-Muñoz, C. Rada and R. von Arnim. 2019. "Secular stagnation and income distribution dynamics." Review of Radical Political Economics, forthcoming.

Marquetti, A. 2004. "Do rising real wages increase the rate of labor-saving technical change? Some econometric evidence." Metroeconomica 55 (4): 432-441.

Ollivaud, P. and D. Turner. 2014. "The effect of the global financial crisis on OECD potential output." OECD Journal: Economic Studies Vol. 2014.

Ollivaud, P., Y. Guillemette and D. Turner. 2016. "Links between weak investment and the slowdown in productivity and potential output growth across the OECD." OECD Economics Department Working Papers No. 1304. Paris: OECD.

Rada, C. and L. Taylor. 2006. "Empty sources of growth accounting, and empirical replacements 'a la Kaldor and Goodwin with some beef." Structural Change and Economic Dynamics 17: 486-500.

Shaikh, A. 1974. "Laws of production and laws of algebra: the HUMBUG production function." The Review of Economics and Statistics 56 (1): 115-120.

Simon, H. A. and F. K. Levy. 1963. "A note on the Cobb-Douglas function." The Review of Economic Studies 30 (2): 93-4.

Solow, R. M. 1957. "Technical change and the aggregate production function." The Review of Economics and Statistics 39 (3): 312-320.

Storm, S. and C.W.M. Naastepad. 2012. Macroeconomics beyond the NAIRU. Cambridge, Mass.: Harvard University Press. 
Storm, S. 2017. "The new normal: demand, secular stagnation, and the vanishing middle class.' International Journal of Political Economy 46 (4): 169-210.

Summers, L.H. 2013. "Speech at the IMF Economic Forum." 14th Annual IMF Research Conference: Crises Yesterday and Today, Nov. 8, 2013.

Summers, L.H. 2015. "Demand side secular stagnation.” American Economic Review: Papers \& Proceedings 105 (5): 60-65.

Syverson, C. 2016. "Challenges to mismeasurement explanations for the U.S. productivity slowdown.” NBER Working Paper Series WP 21974. Cambridge, MA: National Bureau of Economic Research.

Taylor, L., D.K. Foley and A. Rezai. 2019. "Demand drives growth all the way: Goodwin, Kaldor, Pasinetti and the steady state." Cambridge Journal of Economics 43 (5): 1333-1352. 